\title{
Effects of service experience on customer responses to a hotel chain
}

\author{
Rafael Bravo, Eva Martinez and Jose M. Pina \\ Faculty of Business and Economics, University of Zaragoza, Zaragoza, Spain
}

\begin{abstract}
Purpose - This paper aims to analyse customer experience in a hotel and its impact on customer attitudes to both the individual hotel and the hotel chain. Specifically, the study focuses on the effects of service perceptions on emotions, satisfaction, attitude to hotel chain, intention to return, scepticism towards negative information and Word of Mouth (WOM).

Design/methodology/approach - An empirical study was carried out on a sample of 300 individuals. Data were analysed through structural equation modelling.

Findings - Service perceptions and emotions elicited by an individual hotel influence the customer response towards the hotel chain. Among all the outcomes considered, the strongest effects are found on WOM.

Originality/value - This paper develops and empirically tests an original model that integrates the customer experience in an individual hotel and the customer response to the hotel chain. This model includes variables that have recently been considered in the literature, such as scepticism towards negative information, in combination with more traditional outcomes such as intention to return or WOM.
\end{abstract}

Keywords Scepticism, Service experience, Customer emotions, Hotel chain, Service perceptions

Paper type Research paper

\section{Introduction}

In the past decade, the topic of customer experience with a brand has gained importance in management. The development of new methods and practices in businesses together with the appearance of recent academic works with original proposals and metrics are fostering the interest of researchers and practitioners (Brakus et al., 2009; Oh et al., 2015). To manage the customer experience, brand managers carefully track the different touchpoints between the brand and the customer. The aim is to align all these touchpoints with the brand promise to build a specific brand experience (Iglesias et al., 2011).

In comparison with physical products, consumer experience in a service is particularly crucial because of its intangible nature (Grace and O'Cass, 2004). In service industries, prior positive customer experiences with the brand may act as a powerful determinant of their attitude towards the brand and future behaviours (Iglesias et al., 2011). This applies to the tourism sector and the hospitality industry, where customers' experiences with a particular hotel will be a trust generator that may influence their attitude and behaviour in relation to that hotel brand (Xu and Chan, 2010; So and King, 2010). Hotel managers aim to ensure positive and multidimensional experiences for their customers to gain a differentiated position in customers' minds (Xu and Chan, 2010). A well-managed hotel brand should be able to satisfy experiential needs to create positive experiences (Keller and Lehmann, 2006).

This research was supported by the Government of Spain (I + D+I project ECO2013-41257-P) and the Government of Aragón and the European Social Fund (project "Generés" S-09).
Customer responses to a hotel chain

Received 14 September 2017 Revised 14 December 2017 15 March 2018 Accepted 22 April 2018

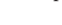


Because of the managerial importance of customer experience in the hotel industry, the academic literature has made and is still making important efforts by developing works to analyse the customer experience and its outcomes from different perspectives (Khan et al., 2015; Jasinskas et al., 2016; So et al., 2016; Gallarza et al., 2017). However, and even though the literature on the hotel industry is ample, there are gaps that still need to be filled.

To the best of our knowledge, there is a lack of empirical evidence about the impact that customer experience of an individual hotel of a chain (e.g. NH Madrid Atocha) may have on the customers' attitudes and behaviour in relation to that hotel chain brand (e.g. NH hotels). The purpose of this study is thus to build on the growing body of literature on branding (Kayaman and Arasli, 2007; So and King, 2010) and customer experience (Xu and Chan, 2010; Khan et al., 2015; Kranzbühler et al., 2017) with a focus on the interaction between the individual hotels and the chains through a set of rational and emotional measures.

Accordingly, our main goal in this paper is to analyse the impact that service experience in an individual hotel may have on customer response towards the hotel chain. Specifically, this work studies the effect of service perceptions on emotions elicited by and satisfaction towards the individual hotel, and how these emotions and satisfaction may, in turn, affect the customer's attitude to the hotel chain and, in consequence, determine the customer's intention to return to the hotel chain, as well as customer scepticism towards negative information and word of mouth (WOM).

The results obtained from this work may contribute to the academic literature and managerial practice. From the perspective of academic research, the main contribution of the present study is the proposal and validation of a theoretical model that, starting from customer experience with an individual hotel, explains the potential feedback effects on the hotel chain. This model includes variables that have recently been considered in the literature, such as scepticism towards negative information, in combination with more traditional outcomes such as intention to return or WOM. The inclusion of all these variables in the same model may also help us to see in which outcomes a customer's experience in a hotel may produce stronger or lesser effects in the customer's response to the hotel chain. From the managerial standpoint, the results obtained in this empirical work may contribute to determining the effects of each aspect that comprises the service perceptions on the emotions and satisfaction of the customer. The results obtained may help managers to allocate resources accordingly. In addition, the analysis of the effects on the customer response to the hotel chain may also be of interest to hotel managers, contributing to showing the extent of these effects.

The structure of this paper is as follows. It opens with a literature review in Section 2, where the conceptual model is presented and hypotheses are developed. This is followed by the methodology and the analysis of the empirical findings in Section 3. Finally, Section 4 provides the results and Section 5 concludes the paper with discussion.

\section{Literature review}

To understand the effects of the individual hotel on the hotel chain, the model proposed in this paper stems from customer experience. This term refers to a complex construct that may encompass many variables related to the customer's sensory experience, feelings during the experience and concurrent and subsequent appraisals (Klaus and Maklan, 2012, 2013; Kranzbühler et al., 2017; Liu et al., 2017). As a whole, customer experience involves the creating of experiential values (Gallarza et al., 2016, 2017) and goes a step beyond classical constructs like service quality, which is more transaction specific and less emotional (Khan et al., 2015). 
Prior literature refers to customer experience with a brand using different terms such as customer experience (Verhoef et al., 2009; Kranzbühler et al., 2017), brand experience (Brakus et al., 2009) or service experience (Grace and O'Cass, 2004; Pansari and Kumar, 2017). The concept of customer experience uses the perspective of the consumer, whereas the term brand experience draws on the perspective of the brand. The latter may apply not only to the customer, but also to the rest of the stakeholders. In services, the concept of service experience is also used to differentiate the customer experience with services from the customer experience with physical products. In this work, we analyse the customer experience with the brand in a service, therefore any of these terms could be applicable to this case. Grace and O'Cass (2004) and So and King (2010) modelled service experience as a set of customer perceptions leading to customer emotions. As the present work is also interested in analysing the relationship between functional and emotional experiences, the split between the two dimensions will be maintained. However, to avoid any confusion with the previous literature, we will use the term "service perceptions" to refer to the functional side of the service experience and "emotions" to refer to the emotional side.

Hence, the model proposed in this paper analyses the effects of service perceptions on customer emotions elicited by and satisfaction towards a specific hotel and, in turn, its impact on customer attitude towards the hotel chain. Following the work of Grace and O'Cass (2004), three different dimensions have been considered to study service perceptions: core service (main service delivered by the hotel), employee service (behaviour and performance of employees) and servicescape (visual aspects of facilities and employees). Besides the aforementioned variables, the model focuses on three final outcomes: intention to return to the hotel chain, scepticism towards negative information and WOM. This model can be seen in Figure 1. All the relationships refer to the hypotheses that are going to be tested in this work.

The sequence of relationships underlying the model is based on three main theories. First, the "hierarchy of effects" theory considers that customer behaviour is initially driven by cognitive factors, which causes an affective evaluation that ultimately lead to conative activity (Lavidge and Steiner, 1961; O'Brien, 1971). This theory, which was initially proposed to understand the effect of advertising on customers (Lavidge and Steiner, 1961), can be helpful to understand the linkages between customer experience in a single hotel and their attitudes and behaviours towards the hotel chain. Thus, in our model, satisfaction and emotion synthesise the affective assessment of the customer experience with an individual hotel and will be the drivers of attitudinal and behavioural responses towards the hotel chain. Second, according to the "signalling theory" (Wernerfelt, 1988), a multiproduct firm can use its reputation as a signal of quality when introducing a new experience good. A

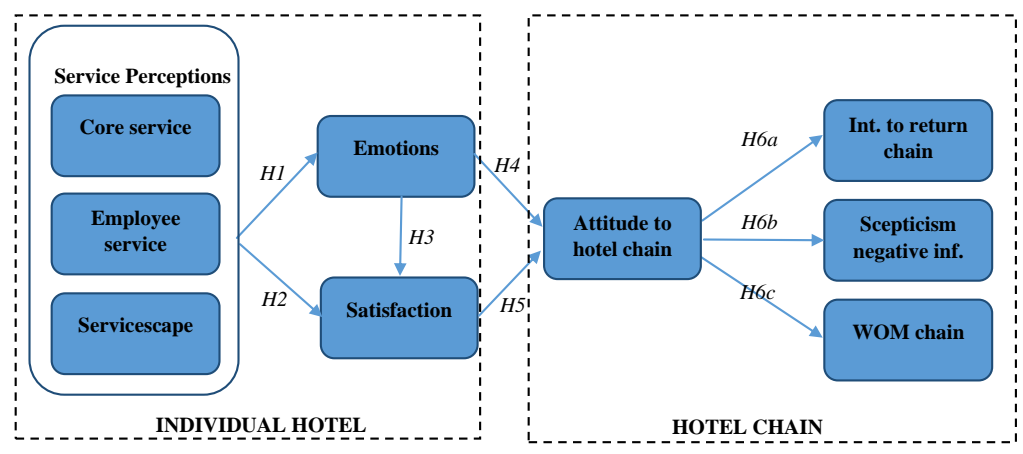

Figure 1. Model proposed 
chain of hotels can be a case of umbrella branding, where individual hotels that belong to a chain uses the same brand name. Customers will consider their experiences with the individual hotel as cues to form their evaluation of the whole chain. Finally, the model is rooted in the "categorization theory" which posits that attitudes toward a stimulus, such as a specific hotel, are directly related to attitudes associated with the activated category (Fiske, 1982). Applied to branding issues, Aaker and Keller (1990) posit that a consumer would evaluate a brand extension depending on the similarity or fit between the original brand and the extension. According to this, they would transfer quality perceptions of the brand to the new brand extension. In this particular case of a chain of hotels, because they all belong to the same category, we may also think that this transfer of quality perceptions from the individual hotel to the hotel chain is going to happen. Both the signalling and categorisation theories lead us to expect a feedback effect from the individual hotel to the hotel chain depending on the customer experience and affective outcomes.

\section{Proposed hypotheses}

Regarding the effects of service perceptions on customer emotions, customer experience of a particular service brand is going to produce an immediate emotional response in that customer. Verhoef et al. (2009) posit that customer experience "involves the customer's cognitive, affective, emotional, social and physical response to the entity, product and service". In the same vein, Klaus and Maklan (2013, p. 228) state that this term refers to "the customers' cognitive and affective assessment of all direct and indirect encounters with the firm relating to their purchasing behaviour". Thus, among other outcomes, the service experience produces an emotional response in the customer, and superior brand experiences may promote strong emotional responses (Bitner, 1992; Iglesias et al., 2011).

There is a vast array of literature dealing with the antecedents of emotions and customer feelings. This is because these emotions and feelings determine customer reactions and purchase behaviours (Babin and Babin, 2001; Grace and O'Cass, 2004) which, in turn, determine companies' economic performance. There are many different classifications of emotions dealing with various feelings such as joy, anger, sadness, guilt, fear, pleasantness, excitement and so on (Ali et al., 2016). Although emotions are difficult to classify in terms of positive or negative, a customer who is pleased or relaxed as a result of a service experience is more likely to be satisfied than a customer who is nervous or annoyed (Burns and Neisner, 2006; Brakus et al., 2009).

In the hospitality industry, Jani and Han (2011) posit that service encounters are crucial in customer experience to determine customer emotions. The service received from hotel personnel may trigger positive or negative emotions in the customer, and every service encounter between the customer and the personnel may produce different emotions. The personnel form the human connection between the company brand and the customer (Punjaisri and Wilson, 2011). Because of their importance, Alloza (2008) refers to employees as the agents who bring to life the values and brand positioning of the company.

Nevertheless, personnel are not the only dimension of service perceptions that has the potential to determine customer emotions elicited by a hotel brand experience. The core service and the servicescape are also relevant factors to consider. Long waits, uncomfortable rooms or, generally speaking, a service that does not suit the needs of the customer may provoke negative emotional responses (Grace and O'Cass, 2004). On the other hand, a customer perception of an extraordinary service experience may result in positive emotional responses, and lead the hotel brand to be differentiated from the rest (Iglesias et al., 2011). In consequence, hotel managers try to stimulate customers' senses and feelings with prompt 
service, careful employee behaviour, and facilities and rooms that are aligned with customer preferences.

Previous works have empirically shown the relationship between different aspects of service perceptions and customer emotions (Grace and O'Cass, 2004; Iglesias et al., 2011; Lin and Liang, 2011; Ali et al., 2016). In our particular context, we also expect that service perceptions will have a positive effect on customer emotions. Therefore, we propose the following hypothesis:

\section{H1. Service perceptions have a positive effect on emotions.}

Service perceptions and customer emotions can also affect the level of customer satisfaction with the service brand. Customer satisfaction with the brand is the response to both tangible and intangible brand stimuli, and it depends on a customer's prior expectations of the brand (Grace and O'Cass, 2004; Ryu et al., 2012). Thus, aspects related to core service, employee service and servicescape are also stimuli that can affect customer satisfaction. Service experiences provide value to the customer, and this value may lead to satisfaction when the customer's expectations are met (Brakus et al., 2009).

The effects of service perceptions and emotions on satisfaction have been studied in different streams of research. Environmental psychology, marketing and organisational research have analysed the impact of the diverse aspects of the service experience. There are studies that focus on the effects of the physical environment and specific design factors on customer satisfaction (Chang, 2000; Jang and Namkung, 2009; Lin and Liang, 2011), whereas other works deal with aspects of the servicescape or the core service (Bitner, 1992; Leong et al., 1997; Babin and Babin, 2001). Some of these studies have also empirically proved these effects of the service experience (Han and Back, 2007; Khan et al., 2015; Ali et al., 2016), and it is important to highlight that the effects of the service experience on satisfaction have been confirmed both directly and indirectly via customer emotions (Grace and O'Cass, 2004; Lin and Liang, 2011).

Moreover, the impact of the customer experience on satisfaction has been proved in diverse sectors such as cars, banks, dental services and hairstylists (McDougall and Levesque, 2000; Grace and O'Cass, 2004; Iglesias et al., 2011). In the light of these works, we may also expect to find a positive effect of service perceptions on customer satisfaction, both directly and indirectly through emotions, in the context of hotel services. Thus, we propose:

H2. Service perceptions have a positive effect on brand satisfaction.

\section{H3. Emotions have a positive effect on brand satisfaction.}

Having positive experiences during their stay in terms of emotions and satisfaction should improve customers' attitude towards a hotel chain as a whole. In their empirical model tested in the banking sector, Grace and O'Cass (2004) showed that brand attitude is directly influenced by satisfaction and indirectly by the feelings aroused in the service experience. However, we propose that emotions can also have a direct effect on the attitude towards the chain. Recent research reveals a direct path between customer emotions and service brand attitudes (Ivens et al., 2015; Kim et al., 2016). In this sense, Kim et al. (1998) proved that affect can shape brand attitudes even in the absence of product beliefs.

A positive link between the attitude towards an individual hotel and the attitude towards the whole chain can be explained by Wernerfelt's (1988) "signalling theory". Drawing on this theory, Erdem (1998) showed that the brand experience is a sign of the quality of any other product associated with the brand, reducing purchasing risks and increasing consumers' 
utility. In general, experience is one of the main determinants of brand perceptions and assessments (So and King, 2010; Shen and Liu, 2015) as well as of the formation of brand images (Keller, 1993). As the hotel chain acts as a mental category that embodies the associations linked to the specific hotels, a retrieval and transference of beliefs and affect is expected to occur (Fiske, 1982).

In the retail sector, researchers report the existence of reciprocal relationships between consumers' attitude to specific stores and their chains (Chebat et al., 2006; Helgesen et al., 2010; Swoboda et al., 2013; Van Lin and Gijsbrechts, 2014). In the hotel industry, So and King (2010) found that experience with a particular chain influences the chain's brand equity.

In general, studies conducted in the context of services reveal that consumer satisfaction, as a result of the gap between expectations and perceptions, will influence attitude to the brand (Shin and Elliott, 2001; Krystallis and Chrysochou, 2014). This attitude will also depend on specific emotions arising from the consumer's interaction with the brand (Ivens et al., 2015; Kim et al., 2016). Therefore, for the specific case of hotels, we propose the following hypotheses:

\section{H4. Emotions have a positive effect on customer attitude to the hotel chain}

\section{H5. Brand satisfaction has a positive effect on customer attitude to the hotel chain}

In the marketing literature, there is a consensus that brand loyalty depends on the overall consumer disposition towards the brand (Dick and Basu, 1994; Chaudhuri and Holbrook, 2001). Drawing on the hierarchy of effects theory, brand attitude will be the intermediate link between consumers' perceptions and their buying behaviour (O'Brien, 1971; Barry, 2002). In this work, we consider three behavioural responses of consumers that reflect both their loyalty and their engagement: intention to return, scepticism towards negative information and WOM.

By analysing different sectors, including the tourism sector, brand attitude has been found to influence purchase intentions (Bruhn et al., 2012; Krystallis and Chrysochou, 2014) and recommendations (Krystallis and Chrysochou, 2014). In retailing, there is also empirical evidence on the effect of brand attitude on these two factors (Hutter and Hoffmann, 2014).

Despite being a novel variable in the literature, Wolter and Cronin (2016) consider scepticism towards negative information as a customer-based outcome at the same level as other traditional variables like WOM or attitudinal loyalty (purchase intentions). They found that consumers who are emotionally identified with a company are less likely to engage in negative WOM and are more sceptical about the negative information they find about the company. As the attitude towards the brand has an emotional nature, a similar relationship can be expected in the effect of attitude towards the chain on different customer outcomes. Hence, we state:

H6a. Customer attitude to the hotel chain has a positive effect on intention to return

$H 6 b$. Customer attitude to the hotel chain has a positive effect on scepticism towards negative information

H6c. Customer attitude to the hotel chain has a positive effect on WOM 


\section{Methodology}

To test the hypotheses, an empirical study was carried out in Spain in the first quarter of 2017. The aim was to analyse consumers' opinions about their most recent stay in a hotel with three stars or more that belongs to a chain. Data were gathered by means of a telephone survey carried out by a market research company. The sample was composed of 300 individuals, with 298 valid responses. Characteristics of the final sample can be seen in Table I.

Regarding the variable measurement, the scales used in this study were previously tested in the literature. Some of them were adapted to the specific context, and all of them are ten-point Likert scales. The composition of the scales and their references to prior works are shown in Table II. Information about means, standard deviations, skew and kurtosis is also included there.

Table II shows that all the measured factors are unidimensional except for service perceptions. This construct was approached through a scale measuring attitudes toward the core service, employee service and servicescape (Grace and O'Cass, 2004; So and King, 2010). In the literature, there are alternative scales to measure service experience including the customer experience quality (EXQ) scale of Klaus and Maklan $(2012,2013)$ and the scales based on the pioneering studies of Holbrook (1999) (Gallarza et al., 2016, 2017) and Pine and Gilmore (1998) (Mody et al., 2017). Although these scales incorporate both emotional and functional aspects of customer experience, none has reached sufficient consensus in the literature. Moreover, they usually include items that are difficult to remember for customers that had their consumption experience a long time ago. Although the time lag between the experience and the survey may introduce a time bias when measuring emotions, the "remembered" experience can be a reliable predictor of future customer behaviour towards the hotel chain. This approach may also be appropriate to measure customers' perceptions and attitudes of an ample sample of hotels in comparison with other methodologies.

The potential existence of problems related to common method bias was controlled for through procedural and statistical methods (Podsakoff et al., 2003). In relation to procedural methods, the study guaranteed the respondents' anonymity and the confidentiality of the information. With regard to statistical procedures, an additional and non-related question was included in the questionnaire to control for common method bias. As expected, this question was not highly correlated with the concepts analysed in the study. Moreover, Harman's single-factor test was also conducted by means of confirmatory factor analysis using EQS 6.2. This test showed that the goodness of fit for the measurement model in which all the variables loaded onto a single factor was substantially lower than the goodness of fit for the model where every item loaded onto its corresponding latent variable. All in all, there is no evidence to suggest the presence of common method bias in this study.

Demographic

Gender

Men

Women

Table I.

8.7 Sample composition 


\section{IJCHM}

Service perceptions (based on Grace and O'Cass, 2004; So and King, 2010)

Core Service

CORE1 The hotel suits my needs

CORE2 It is reliable

CORE3 It is superior to other hotels

CORE4 It is a good service

CORE5 It is a quality service

Employee Service

EMPL1 Employees provide a prompt service

EMPL2 They are willing to help

EMPL3 They are never too busy for me

EMPL4 I can trust employees

EMPL5 I feel safe with them

EMPL6 Employees are polite

EMPL7 They give personal attention

Servicescape

SCAPE1 Employees are neat

SCAPE2 Facilities suit service type

SCAPE3 Facilities are up to date

SCAPE4 Facilities are attractive

Emotions (based on Russell and Pratt, 1980; Mattila and Wirtz, 2000)

EMO1 My stay in the hotel was pleasant

EMO2 My stay in the hotel was relaxing

EMO3 My stay in the hotel was arousing

EMO4 My stay in the hotel was exciting

Satisfaction (based on Ali et al., 2016)

SAT1 I am satisfied with my decision to stay in this hotel

SAT2 My choice to stay in this hotel was a wise one

SAT3 I think I did the right thing when I chose to stay in this hotel

$\begin{array}{llll}8.45 & 1.17 & -0.51 & 0.27\end{array}$

$\begin{array}{llll}8.17 & 1.21 & -0.33 & -0.09\end{array}$

$\begin{array}{llll}7.81 & 1.49 & -0.96 & 1.52\end{array}$

$\begin{array}{llll}8.33 & 1.27 & -0.91 & 1.43\end{array}$

$\begin{array}{llll}8.24 & 1.30 & -0.92 & 1.37\end{array}$

$\begin{array}{llll}8.29 & 1.17 & -0.95 & 1.88\end{array}$

$\begin{array}{llll}8.24 & 1.22 & -0.68 & 0.79\end{array}$

$\begin{array}{llll}8.03 & 1.27 & -0.75 & 1.13\end{array}$

$\begin{array}{llll}8.27 & 1.26 & -0.70 & 0.79\end{array}$

$\begin{array}{llll}8.39 & 1.27 & -0.69 & 0.30\end{array}$

$\begin{array}{llll}8.83 & 1.07 & -0.68 & 0.11\end{array}$

$\begin{array}{llll}8.00 & 1.42 & -0.94 & 2.68\end{array}$

$\begin{array}{llll}8.59 & 1.16 & -0.74 & 0.63\end{array}$

$\begin{array}{llll}8.29 & 1.26 & -1.18 & 3.52\end{array}$

$\begin{array}{llll}8.08 & 1.33 & -1.19 & 3.58\end{array}$

$\begin{array}{llll}8.33 & 1.26 & -0.87 & 1.43\end{array}$

$\begin{array}{llll}8.61 & 1.12 & -0.77 & 0.79\end{array}$

$\begin{array}{llll}8.11 & 1.44 & -0.87 & 1.11\end{array}$

$\begin{array}{llll}7.64 & 1.50 & -0.48 & -0.04\end{array}$

$\begin{array}{llll}7.48 & 1.60 & -0.43 & -0.33\end{array}$

$\begin{array}{llll}8.61 & 1.23 & -0.84 & 0.89\end{array}$

$\begin{array}{llll}8.62 & 1.30 & -1.21 & 2.71\end{array}$

$\begin{array}{llll}8.69 & 1.32 & -1.18 & 1.48\end{array}$

Attitude to hotel chain (based on Ferraro et al., 2013)

ATT1 I like this hotel chain

ATT2 I have a favourable opinion of this hotel chain

ATT3 It is a good hotel chain

Intention to return (based on Kim et al., 2009)

INT1 I'm likely to come back to this hotel chain in the future

$\begin{array}{llll}8.29 & 1.23 & -0.93 & 1.69\end{array}$

$\begin{array}{llll}8.33 & 1.19 & -0.98 & 1.81\end{array}$

$\begin{array}{llll}8.41 & 1.24 & -1.22 & 2.72\end{array}$

INT2 In my next stay in a hotel, I will consider this hotel chain as my

$\begin{array}{lll}7.98 & 1.70 & -1.24\end{array}$

2.18 first option

$\begin{array}{lll}7.49 & 1.70 & -1.27\end{array}$

2.70

Scepticism towards negative information (based on Wolter and Cronin, 2016)

(Imagine that you read a piece of news stating that this hotel chain is one of the worst in the industry. How would you react to this piece of news?)

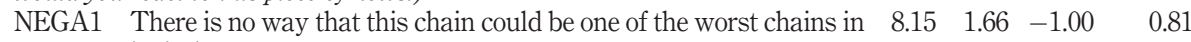
its industry

NEGA2 I would refuse to believe this piece of news

NEGA3 This piece of news can't be trusted

$\begin{array}{llll}7.77 & 1.87 & -1.06 & 0.89\end{array}$

Wom chain (based on Rondán-Cataluña et al., 2015)

WOM1 I'm likely to say good things about this hotel chain

$\begin{array}{llll}7.87 & 1.93 & -1.06 & 0.91\end{array}$

WOM2 I would recommend this hotel chain to my family

WOM3 If my friends were looking for a hotel, I would tell them to

$8.50 \quad 1.42-1.22 \quad 1.94$

$\begin{array}{llll}8.40 & 1.56 & -1.44 & 2.91\end{array}$

Table II.

Composition of the scales
Note: All the factors were measured by means of ten-point Likert scales. Standard error in skew was 0.141 and in kurtosis 0.281 


\section{Results}

Once the data were gathered, the first step was to analyse the validity and reliability of the scales before testing the model. Because of the multidimensional nature of service perceptions, this construct was operationalised as a second-order factor model following a two-step approximation method (Chin, 2010). The construct was composed of three factors: core service, employee service and servicescape. The model was tested using partial least squares (PLS) regression with SmartPLS software. In comparison to traditional covariancebased structural equation modelling, this methodology is appropriate when the interest of the study focuses on prediction and on theory development, rather than on strong theory confirmation (Reinartz et al., 2009). This is in accordance with the scope of this research, which focuses on predicting different dependent variables such as emotions elicited by and satisfaction with a specific hotel, attitude to the hotel chain and other outcomes. Furthermore, the use of PLS is preferable when the model, as in our case, includes a large number of indicators and latent variables and when the data is non-normally distributed (Chin, 2010; Ringle et al., 2012). Regarding convergent validity, all the factor loadings were above the common threshold of 0.5 (Table III). In relation to the reliability properties, the results show that the values of Cronbach's alpha, composite reliability and average variance extracted (AVE) for all the constructs were above the widely accepted limits of 0.8, 0.7 and 0.5 , respectively.

Finally, the discriminant validity of the scales was analysed by comparing each construct's AVE with the squared correlation of that construct in relation to the rest of the variables (Fornell and Larcker, 1981). In all cases, the AVE for any two constructs was always greater than the squared correlations and, therefore, discriminant validity was supported for the scales.

Table IV shows the results of the structural model proposed in Figure 1. To assess the significance of the path coefficients, a bootstrap resampling technique with 5,000 subsamples was used. The results revealed that all the factorial loadings were significant at 5 per cent. The Stone-Geisser test criterion $\left(Q^{2}\right)$ exceeded the threshold of 0 for all the dependent variables, supporting the predictive relevance of the model. Finally, the $R^{2}$ values of the dependent variables were also above the common threshold of 10 per cent.

Then we proceeded to analyse each of the hypotheses proposed in this model. As can be seen in Table IV, all of them were supported. Regarding H1, the path coefficient was positive and significant, which led us to accept the positive effect of service perceptions on emotions $(\beta=0.72, p<0.05)$. This means that the overall experience of the consumer in the individual hotel produces emotions. The more positive the service perceptions are, the more pleasant, relaxing, arousing and exciting the emotions are.

In relation to $H 2$ and $H 3$, we can see from Table IV that satisfaction was also determined by service perceptions $(\beta=0.67, p<0.05)$ and emotions $(\beta=0.19, p<0.05)$. These results give support to both hypotheses. Thus, service perceptions of the hotel affect both customer emotions and satisfaction. Given the similar beta coefficients, the effects also seem to be similar. Furthermore, the model shows that satisfaction is, in turn, determined by emotions.

$H 4$ to $H 6$ refer to the effects on the hotel chain. We can see from the table that customer emotions towards the individual hotel positively affect attitude to the hotel chain $(\beta=0.28$, $p<0.05)$. Moreover, customer satisfaction with the individual hotel also determines the positive influence on attitude to the hotel chain $(\beta=0.58, p<0.05)$. In consequence, $H 4$ and $H 5$ are supported. Finally, Table IV shows that attitude to the hotel chain also exerts positive effects on intention to return $(\beta=0.59, p<0.05)$, scepticism towards negative information $(\beta=0.52, p<0.05)$ and $\operatorname{WOM}(\beta=0.79, p<0.05)$, which gives support to $H 6 a$, $H 6 b$ and $H 6 c$. 


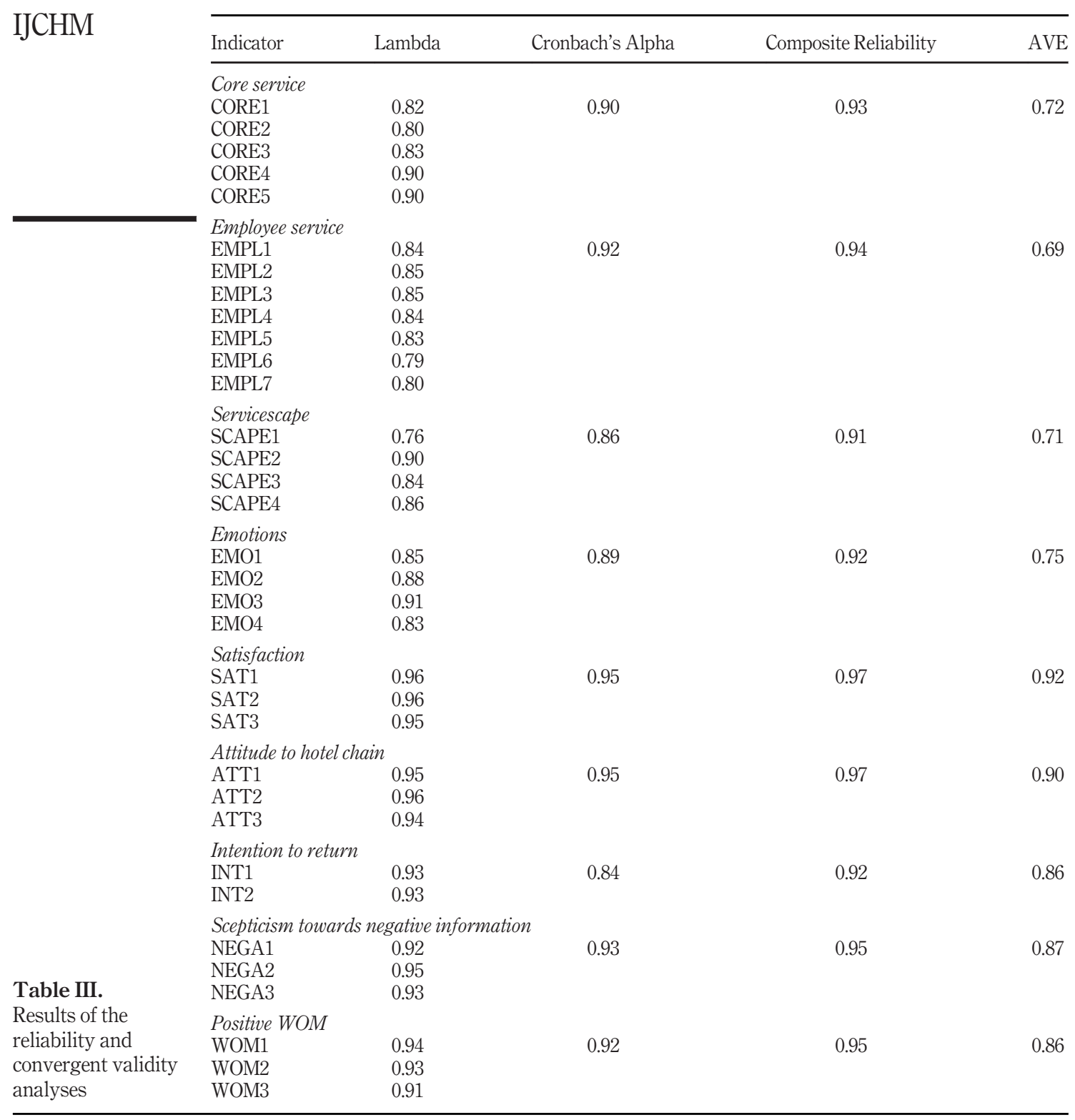

\section{Discussion}

\subsection{Conclusions}

The choice of one strategy or another is fundamental to business success in the hotel industry (Kim and Kim, 2005; Xu and Chan, 2010) where a great number of brands have emerged. Despite their higher than average prices, branded hotel chains outperform non- 


\begin{tabular}{|c|c|c|c|c|c|}
\hline Hypotheses & $\beta$ & $t$-value & $Q^{2}$ & $R^{2}$ & seve \\
\hline H1: Service perceptions $\rightarrow$ Emotions & 0.72 & $22.17^{*}$ & 0.75 & 0.52 & \\
\hline$H 2$ Service perceptions $\rightarrow$ Satisfaction & 0.67 & $13.33^{*}$ & 0.91 & 0.68 & \\
\hline$H 3:$ Emotions $\rightarrow$ Satisfaction & 0.19 & $3.34^{*}$ & & & \\
\hline H4: Emotions $\rightarrow$ Attitude to hotel chain & 0.28 & $4.60^{*}$ & 0.90 & 0.63 & \\
\hline H5: Satisfaction $\rightarrow$ Attitude to hotel chain & 0.58 & $10.88^{*}$ & & & \\
\hline H6a: Attitude to hotel chain $\rightarrow$ Intention to return & 0.59 & $9.97^{*}$ & 0.86 & 0.35 & \\
\hline H6b: Attitude to hotel chain $\rightarrow$ Scepticism towards negative & 0.52 & $9.36^{*}$ & 0.87 & 0.27 & \\
\hline $\begin{array}{l}\text { information } \\
H 6 c \text { : Attitude to hotel chain } \rightarrow \text { WOM chain }\end{array}$ & 0.79 & $25.11^{*}$ & 0.86 & 0.62 & $\begin{array}{r}\text { Table II } \\
\text { Results of th }\end{array}$ \\
\hline Note: ${ }^{*}=$ significant at $p<0.05$ & & & & & \\
\hline
\end{tabular}

branded properties on the level of occupancy, revenues and return on investment (Forgacs, 2003). However, when it comes to the management of hotel brands, it is important to know the implications of associating a particular hotel with a well-known brand. In this work, results obtained show that service perceptions of an individual hotel determine customer satisfaction both directly and indirectly through emotions elicited by the hotel. Moreover, customer emotions towards the individual hotel also affect the customer attitude towards the hotel chain, both directly and indirectly through satisfaction. Finally, the attitude towards the hotel brand explains customer intention to return to the hotel chain, scepticism to negative information and WOM. All these findings lead to extract a series of theoretical and managerial implications.

\subsection{Theoretical implications}

The main contribution of this work is the development and validation of a model to learn how service perceptions and emotions elicited by an individual hotel influence customer response towards the hotel chain. Both the service perceptions and the emotions will reflect the service experience. In this way, our approach attempts to cover the gap between the rational and the experiential approaches in the previous literature (Kranzbühler et al., 2017). All the proposed relationships were supported, which corroborates the academic and practical utility of the model. These results build on the literature on brand management while providing additional support to the theories of the hierarchy of effects, signalling theory and categorization theory. They also indicate that cognitive factors are relevant in highly experiential sectors such as the hotel industry. In accordance with the results, various conclusions can be extracted.

First, it was found that service perceptions influence both emotions and satisfaction, and there is also a direct relationship between the latter two factors. In this work, there is a higher indirect effect of service experience on satisfaction through emotions than in the study of Grace and O'Cass (2004), where the effect of service experience on satisfaction was mainly direct. This may be because, in our study, the focus has been on four emotions: pleasantness, relaxation, arousal and attractiveness whereas the study of Grace and O'Cass (2004) includes other feelings such as happiness, sadness, frustration, etc. These results show that the emotions considered in our study play a key role in determining customer satisfaction. It is not only functional aspects that are above the expectations of the customer that lead to satisfaction. These emotions emerge as a consequence of the service experience, and they are also important aspects to explain customer satisfaction. 
Second, it is also important to highlight the crucial role that emotions play to explain attitude towards the hotel chain both directly and indirectly through satisfaction. According to Pansari and Kumar (2017), the satisfaction and emotions generated in the interaction between the consumer and the brand constitute the main antecedents of customer engagement, the psychological process driving customer loyalty (Bowden, 2009). In our work, emotions and customer satisfaction are the results of service experience in an individual hotel, and both factors exert a significant impact on attitude to the hotel chain. Thus, this model connects customer experience in an individual hotel with the attitudinal response of the customer to the hotel chain, and customer emotions elicited by the hotel is a key element to explain this connection.

Third, the results obtained show that attitude towards the hotel chain determines customer intention to return to the hotel chain, scepticism towards negative information and WOM. The results reveal that the strongest of these effects is that of attitude towards the hotel chain on WOM. This is particularly important in the hospitality industry, where comments and recommendations online and offline are critical in determining the choice of a hotel by other customers (Xie et al., 2016).

\subsection{Managerial implications}

The results obtained have implications that can be useful to companies operating in this sector. They indicate the importance of taking care of individuals' experiences in all their interactions with a brand. Consumers are keen to repeat pleasurable experiences (Brakus et al., 2009), which means that a positive experience in a particular hotel will end up benefiting the entire chain. The truth is that much work remains to be done, however, as hotel brands are increasing and consumers perceive few differences between them (So and King, 2010).

In addition to satisfying customers through rational benefits, hotels can be differentiated by providing customers with emotional benefits. These rational and emotional benefits may result from meeting customers' expectations as well as from triggering positive customer emotions. They will make customers remember their stay as pleasant, relaxing, arousing and exciting. In a highly competitive industry such as the hospitality sector, there are high standards in functional aspects that make it difficult to differentiate one hotel from the others (So et al., 2016). Emotions are not easy to copy, and companies that are able to arouse positive customer emotions may be perceived as different from the rest (Iglesias $e$ t al., 2011). According to our results, these positive emotions may be elicited by improving the perceptions of the core service, employee service and servicescape. Behind these factors, there is a set of specific indicators (employees' politeness, appeal of facilities, etc.) that hotel managers should measure and strengthen as a first step to improving customer experience. Moreover, in the process of developing a positive customer experience, it is necessary to integrate and align the different areas of the organisation such as marketing, operations, human resources, strategy, technology, social media and design (Kandampully et al., 2018).

Tracking the customer experience cannot be limited to the elements of core service, employee attitude and servicescape. Monitorization should also include the customer emotions elicited by the hotel brand experience. So and King (2010) propose different ways to monitorize the service experience in hotels, such as regular focus groups, interviews with customers and mystery shoppers. These authors also recommend that hotel managers introduce employee programmes including free one-night stays to allow service providers to experience the hotel service as a guest and to see how their work behaviour influences customer experience. In view of the results obtained in this study, we would also add the need to monitorize customer emotions periodically. Even if the research methods and programmes are similar to those proposed by So and King (2010), customer emotions should be also considered in the analysis. 
Hotel chains should also know that working on the creation of favourable emotions and attitudes can make future clients more sceptical towards negative information. This result indicates a way to combat the proliferation of both fake news and negative comments on the Internet that threaten the reputation of companies. As Zhang and Hanks (2017) found, a positive mood will increase dopamine levels and could even reduce the scepticism of potential guests towards the information provided by the hotel itself.

\subsection{Limitations and further research}

It must be taken into account that all the data collected refers to hotels of known chains of three or more stars. Therefore, this study disregards other models of establishment with different customer profiles. Business tourism was also ruled out, since the purchasing behaviour is different and depends on other criteria. Addressing these gaps may be an option for future research. Moreover, future work could aim at replicating the model in other service sectors. Given that all the hypotheses were robustly confirmed, the model could be useful in understanding the interaction between individual and umbrella brands across sectors such as retailing, banks, health services and so on.

As in other works, the proposed model constitutes a simplification of reality, not reality itself. Thus, the full spectrum of factors and variables that could influence individual behaviour and attitudes are not contemplated. For example, to measure a construct as rich as emotions, the study is limited to four of the most cited emotional states in previous studies. In the same way, it focuses on the experience with a particular hotel, asking participants about their most memorable experience within the last two years. Thus, future work should analyse the differential effect of different experiences with different hotels in the chain, as well as the experiences provided by the holiday destination itself.

It is also important to highlight that, apart from surveys, there are other methods to analyse customer emotions. Future studies with other methodologies could enrich the results obtained in this work. For instance, in-depth interviews are especially adequate in exploratory studies when it is crucial to study the customer emotions of every interviewee more deeply to extract new insights. Observation is particularly suitable to examine customer emotions in a real setting where customers are not aware of the presence of observers during the service. There are also advanced observational techniques such as neuromarketing which gather neurological and biological data after exposing individuals to marketing stimuli. These methods are timidly emerging in the hospitality research despite their technical and economic challenges (Boz et al., 2017). A longitudinal design with personal surveys could also be an interesting approach to analyse how the emotions experienced immediately after the service consumption are maintained in the short and long term. All of these approaches are complementary and contribute to the knowledge of the topic. Finally, the inclusion of destination image in the model could capture the interest not only of private companies in the hotel sector, but also of the public administrations responsible for promoting local tourism.

\section{References}

Aaker, D.A. and Keller, K.L. (1990), “Consumer evaluations of brand extensions”, Lournal of Marketing, Vol. 54 No. January, pp. 24-41.

Ali, F., Hussain, K. and Omar, R. (2016), "Diagnosing customer experience, emotions and satisfaction in Malaysian resort hotels", European Iournal of Tourism Research, Vol. 12, pp. 25-40.

Alloza, A. (2008), "Brand engagement and brand experience at BBVA, the transformation of a 150 years old company", Corporate Reputation Review, Vol. 11 No. 4, pp. 371-379. 
Babin, B.J. and Babin, B.L. (2001), "Seeking something different? A model of schema typicality, consumer affect, purchase intentions and perceived shopping value", Lournal of Business Research, Vol. 54 No. 2, pp. 89-96.

Barry, T.E. (2002), "In defense of the hierarchy of effects", Journal of Advertising Research, Vol. 42 No. 3, pp. 44-47.

Bitner, M.J. (1992), "Evaluating service encounters: the effects of physical surroundings and employee responses", Journal of Marketing, Vol. 54 No. 2, pp. 69-82.

Bowden, J.L.H. (2009), "The process of customer engagement: a conceptual framework”, Lournal of Marketing Theory and Practice, Vol. 17 No. 1, pp. 63-74.

Boz, H., Arslan, A. and Koc, E. (2017), "Neuromarketing aspect of tourism pricing psychology", Tourism Management Perspectives, Vol. 23, pp. 119-128.

Brakus, J.J., Schmitt, B.H. and Zarantonello, L. (2009), "Brand experience: what is it? How is it measured? Does it affect loyalty?”, Journal of Marketing, Vol. 73 No. 3, pp. 52-68.

Bruhn, M., Schoenmueller, V. and Schäfer, D.B. (2012), "Are social media replacing traditional media in terms of brand equity creation?”, Management Research Review, Vol. 35 No. 9, pp. 770-790.

Burns, D. and Neisner, L. (2006), "Customer satisfaction in a retail setting: the contribution", International Iournal of Retail and Distribution Management. Vol. 31 No. 1, pp. 49-66.

Chang, K. (2000), "The impact of perceived physical environments on customers' satisfaction and return intentions", Lournal of Professional Services Marketing, Vol. 21 No. 2, pp. 75-85.

Chaudhuri, A. and Holbrook, M.B. (2001), "The chain of effects from brand trust and brand affect to brand performance: the role of brand loyalty", Journal of Marketing, Vol. 65 No. 2, pp. 81-93.

Chebat, J.C., Sirgy, M.J. and St-James, V. (2006), "Upscale image transfer from malls to stores: a selfimage congruence explanation", Lournal of Business Research, Vol. 59 No. 12, pp. 1288-1296.

Chin, W.W. (2010), "How to write up and report PLS analyses, Chapter 28" in Vinzi, V.E., Chin, W.W., Henseler, J. and Wang, H. (Eds), Handbook of Partial Least Squares Concepts, Methods and Applications, (Chapter 28), Springer-Verlag, Berlin.

Dick, A.S. and Basu, K. (1994), “Customer loyalty: toward an integrated conceptual framework”, Lournal of the Academy of Marketing Science, Vol. 22 No. 2, pp. 99-113.

Erdem, T. (1998), "An empirical analysis of umbrella branding”, Lournal of Marketing Research, Vol. 35 No. 3, pp. 339-351.

Fiske, S.T. (1982), "Schema-triggered affect: applications to social perception”, in Clark, M. and Fiske, S. (Eds), Affect and Cognition: The 17th Annual Carnegie Symposium on Cognition, Erlbaum, Hillsdale, NJ, pp. 55-78.

Forgacs, G. (2003), "brand asset equilibrium in hotel management", International Iournal of Contemporary Hospitality Management, Vol. 15 No. 6, pp. 340-342.

Fornell, C. and Larcker, D.F. (1981), "Evaluating structural equation models with unobservable variables and measurement error", Journal of Marketing Research, Vol. 18 No. 1, pp. 39-50.

Gallarza, M.G., Arteaga, F., Del Chiappa, G., Gil-Saura, I. and Holbrook, M.B. (2017), “A multidimensional service-value scale based on Holbrook's typology of customer value: bridging the gap between the concept and its measurement", Journal of Service Management, Vol. 28 No. 4, pp. 724-762.

Gallarza, M.G., Arteaga-Moreno, F., Del Chiappa, G. and Gil-Saura, I. (2016), "Intrinsic value dimensions and the value-satisfaction-loyalty chain: a causal model for services", Iournal of Services Marketing, Vol. 30 No. 2, pp. 165-185.

Grace, D. and O'Cass, A. (2004), "Examining service experiences and post-consumption evaluations", Journal of Services Marketing, Vol. 18 No. 6, pp. 450-461.

Han, H. and Back, K.J. (2007), "Investigating the effects of consumption emotions on customer satisfaction and repeat visit intentions in the lodging industry", Journal of Hospitality Marketing and Management, Vol. 15 No. 3, pp. 5-30. 
Helgesen, Ø., Håvold, J.I. and Nesset, E. (2010), "Impacts of store and chain images on the 'quality satisfaction - loyalty process' in petrol retailing", Lournal of Retailing and Consumer Services, Vol. 17 No. 2, pp. 109-118.

Holbrook, M.B. (1999), Consumer Value: A Framework for Analysis and Research, Routledge, London.

Hutter, K. and Hoffmann, S. (2014), "Surprise, surprise: ambient media as promotion tool for retailers", Journal of Retailing, Vol. 90 No. 1, pp. 93-110.

Iglesias, O., Singh, J.J. and Batista-Foguet, J.M. (2011), "The role of brand experience and affective commitment in determining brand loyalty”, Journal of brand Management, Vol. 18 No. 8, pp. 570-582.

Ivens, B.S., Leischnig, A., Muller, B. and Valta, K. (2015), "On the role of brand stereotypes in shaping consumer response toward brands: an empirical examination of direct and mediating effects of warmth and competence", Psvchology and Marketing, Vol. 32 No. 8, pp. 808-820.

Jang, S. and Namkung, Y. (2009), "Perceived quality, emotions and behavioural intentions: application of an extended Mehrabian-Russell model to restaurants", Lournal of Business Research, Vol. 62 No. 4, pp. 451-460.

Jani, D. and Han, H. (2011), "Investigating the key factors affecting behavioural intentions: evidence from a full-service restaurant setting", International Iournal of Contemporary Hospitality Management, Vol. 23 No. 7, pp. 1000-1018.

Jasinskas, E., Streimikiene, D., Svagzdiene, B. and Simanavicius, A. (2016), "Impact of hotel service quality on the loyalty of customers", Economic Research-Ekonomska Istraživania , Vol. 29 No. 1, pp. 559-572.

Kandampully, J., ; Zhan, T. and Jaakkola, E. (2018), "Customer experience management in hospitality. A literature synthesis, new understanding and research agenda", International Iournal of Contemporary Hospitality Management, Vol. 30 No. 1, pp. 21-56.

Kayaman, R. and Arasli, H. (2007), "Customer based brand equity: evidence from the hotel industry", Managing Service Qualitv: An International Iournal, Vol. 17 No. 1, pp. 92-109.

Keller, K.L. (1993), “Conceptualizing, measuring, and managing customer-based brand equity”, Lournal of Marketing, Vol. 57 No. 1, pp. 1-22.

Keller, K.L. and Lehmann, D.R. (2006), "brands and branding: research findings and future priorities", Marketing Science, Vol. 25 No. 6, pp. 740-759.

Khan, I., Garg, R.J. and Rahman, Z. (2015), "Customer service experience in hotel operations: an empirical analysis", Procedia-Social and Behavioral Sciences, Vol. 189, pp. $266-274$.

Kim, H.B. and Kim, W.G. (2005), "The relationship between brand equity and firms' performance in luxury hotels and chain restaurants", Tourism Management, Vol. 26 No. 4, pp. 549-560.

Kim, J., Lim, J.S. and Bhargava, M. (1998), "The role of affect in attitude formation: a classical conditioning approach", Journal of the Academv of Marketing Science, Vol. 26 No. 2, pp. 143-152.

Kim, S., Park, G., Lee, Y. and Choi, S. (2016), "Customer emotions and their triggers in luxury retail: understanding the effects of customer emotions before and after entering a luxury shop", Journal of Business Research, Vol. 69 No. 12, pp. 5809-5818.

Klaus, P. and Maklan, S. (2012), "EXQ: a multiple-item scale for assessing service experience", Lournal of Service Management, pp. 1-24.

Klaus, P. and Maklan, S. (2013), "Towards a better measure of customer experience", International Lournal of Market Research, Vol. 55 No. 2, pp. 227-246.

Kranzbühler, A.M., M.H.P, K., Morgan, R.E. and Teerling, M. (2017), "The multilevel nature of customer experience research: an integrative review and research agenda", International Iournal of Management Reviews, Vol. 20 No. 2, pp. 433-456, doi: 10.1111/ijmr.12140.

Krystallis, A. and Chrysochou, P. (2014), "The effects of service brand dimensions on brand loyalty", Lournal of Retailing and Consumer Services, Vol. 21 No. 2, pp. 139-147.

Lavidge, R.C. and Steiner, G.A. (1961), "A model for predictive measurements of advertising effectiveness”, Journal of Marketing, Vol. 25 No. 6, pp. 59-62. 
Leong, S.M., Ang, S.W. and Low, L.H.L. (1997), "Effects of physical environment and locus of control on service evaluation”, Lournal of Retailing and Consumer Services, Vol. 4 No. 4, pp. 231-237.

Lin, J. and Liang, H. (2011), "The influence of service environments on customer emotion and service outcomes", Managing Service Quality: An International Journal, Vol. 21 No. 4, pp. 350-372.

Liu, W., Sparks, B. and Coghlan, A. (2017), "Fun, inspiration and discovery: from momentary experiences to overall evaluations", International Iournal of Contemporary Hospitality Management, Vol. 29 No. 7, pp. 1937-1955.

McDougall, G.H.G. and Levesque, T. (2000), "Customer satisfaction with services: putting perceived value into the equation", Lournal of Services Marketing, Vol. 14 No. 5, pp. 392-410.

Mody, M.A., Suess, C. and Lehto, X. (2017), "The accommodation experiencescape: a comparative assessment of hotels and airbnb", International Iournal of Contemporary Hospitality Management, Vol. 29 No. 9, pp. 2377-2404.

O’Brien, T.V. (1971), “Tracking consumer decision making”, Journal of Marketing, Vol. 35 No. 1, pp. 34-40.

Oh, H., Fiore, A.M. and Jeoung, M. (2015), "Measuring experience economy concepts: tourism and applications", Lournal of Travel Research, Vol. 46 No. 2, pp. 119-132.

Pansari, A. and Kumar, V. (2017), "Customer engagement: the construct, antecedents, and consequences”, Lournal of the Academy of Marketing Science, Vol. 45 No. 3, pp. 294-311.

Pine, B.J. and Gilmore, J. (1998), "Welcome to the experience economy", Harvard Business Review, Vol. 76 No. 4, pp. 97-105.

Podsakoff, P.M., MacKenzie, S.B., Lee, J.Y. and Podsakoff, N.P. (2003), "Common method biases in behavioral research: a critical review of the literature and recommended remedies", Lournal of Applied Psychology, Vol. 88 No. 5, pp. 879-903.

Punjaisri, K. and Wilson, A. (2011), "Internal branding process: key mechanisms, outcomes and moderating factors", Eurobean Iournal of Marketing, Vol. 45 Nos 9/10, pp. 1521-1537.

Reinartz, W., Haenlein, M. and Henseler, J. (2009), "An empirical comparison of the efficacy of covariance-based and variance-based SEM", International Journal of Research in Marketing, Vol. 26 No. 4, pp. 332-344.

Ringle, C.M., Sarstedt, M. and Straub, D. (2012), “A critical look at the use of PLS-SEM", MIS Quarterlv, Vol. 36 No. 1, pp. 3-14.

Rondán-Cataluña, F.J., Arenas-Gaitán, J. and Ramírez-Correa, P. (2015), "Travel buying behavior in social network site users: to buy online vs offline", Lournal of Theoretical and Applied Electronic Commerce Research, Vol. 10 No. 1, pp. 49-62.

Ryu, K., Lee, H. and Kim, W. (2012), "The influence of the quality of the physical environment, food, and service on restaurant image, customer perceived value, customer satisfaction and behavioural intentions", International Iournal of Contemporary Hospitality Management, Vol. 24 No. 2, pp. 200-223.

Shen, C.C. and Liu, D.J. (2015), "Correlation between the homestay experience and brand equity: using the yuehetang rural residence as a case study", Lournal of Hospitality and Tourism Technology, Vol. 6 No. 1, pp. 59-72.

Shin, D. and Elliott, K.M. (2001), "Measuring customers' overall satisfaction: a multi-attributes assessment”, Services Marketing Quarterly, Vol. 22 No. 1, pp. 3-19.

So, K.K.F. and King, C. (2010), "When experience matters: building and measuring hotel brand equity. The customers' perspective", International Journal of Contemporary Hospitality Management, Vol. 22 No. 5, pp. 589-608.

So, K.K.F., King, C., Sparks, B.A. and Wang, Y. (2016), "The role of customer engagement in building consumer loyalty to tourism brands", Journal of Travel Research, Vol. 55 No. 1, pp. 64-78.

Swoboda, B., Berg, B. and Schramm-Klein, H. (2013), "Reciprocal effects of the corporate reputation and store equity of retailers", Journal of Retailing, Vol. 89 No. 4, pp. 447-459. 
Van Lin, A. and Gijsbrechts, E. (2014), "Shopper loyalty to whom? Chain versus outlet loyalty in the context of store acquisitions", Lournal of Marketing Research, Vol. 51 No. 3, pp. 352-370.

Verhoef, P.C., Lemon, K.N., Parasuraman, A., Roggeveen, A., Tsioros, M. and Sclesinger, L.A. (2009), "Customer experience creation: determinants, dynamics and management strategies", Lournal of Retailing, Vol. 85 No. 1, pp. 31-41.

Wernerfelt, B. (1988), "Umbrella branding as a signal of new product quality: an example of signaling by posting a bond", Rand Journal of Economics, Vol. 19 No. 3, pp. 458-466.

Wolter, J.S. and Cronin, J.J. (2016), "Re-conceptualizing cognitive and affective customer-company identification: the role of self-motives and different customer-based outcomes", Lournal of the Academv of Marketing Science, Vol. 44 No. 3, pp. 397-413.

Xie, K.L., Zhang, Z., Zhang, Z., Singh, A. and Lee, S.K. (2016), "Effects of managerial response on consumer eWOM and hotel performance", International Journal of Contemporary Hospitality Management, Vol. 28 No. 9, pp. 2013-2034.

Xu, J.B. and Chan, A. (2010), “A conceptual framework of hotel experience and customer-based brand equity: Some research questions and implications", International Iournal of Contemporary Hospitality Management, Vol. 22 No. 2, pp. 174-193.

Zhang, L. and Hanks, L. (2017), "Consumer skepticism towards CSR messages: the joint effects of processing fluency, individuals' need for cognition and mood", International Iournal of Contemporary Hospitality Management, Vol. 29 No. 8, pp. 2070-2084.

\section{About the authors}

Rafael Bravo is Senior Lecturer at Universidad de Zaragoza. He holds a $\mathrm{PhD}$ since 2006 and his main research interest are focussed on consumer research and brand management. He has participated in different research projects, and nowadays he is deepening on the study of corporate brand identity on services. He has several publications in refereed journals. He has also published chapters in books, working papers and conference proceedings, and he is a frequent reviewer in many journals and chair in conferences. His work has been published in journals such as Journal of Business Research, Service Industries Journal and Journal of Business Ethics. Rafael Bravo is the corresponding author can be contacted at: rbravo@unizar.es

Eva Martínez is Professor in Marketing at the Faculty of Business and Economics of the University of Zaragoza. She is a member of the research group Generés recognised by the Government of Aragón. Her research interests include green consumers' behaviour and brand management. She has published her research in journals like European Journal of Marketing, Journal of Business Research, Journal of Consumer Marketing, Business Strategy and the Environment, Journal of Strategic Marketing, Journal of Business Ethics, Tourism Management or Computers and Education.

José M. Pina holds the position of Senior Lecturer at the Department of Marketing in the University of Zaragoza (Spain), where he obtained his $\mathrm{PhD}$ in 2006. He has co-authored numerous journals articles, conference proceedings and book contributions on different branding topics such as brand extensions, brand alliances, brand image, brand equity and corporate branding. His main publications can be found in the following journals: Corporate Social Responsibility and Environmental Management, European Journal of Marketing, Journal of Business Ethics, Journal of Business Research, Online Information Review and Service Industries Journal.

For instructions on how to order reprints of this article, please visit our website: www.emeraldgrouppublishing.com/licensing/reprints.htm Or contact us for further details: permissions@emeraldinsight.com 